\title{
Parasitism by a Digenea in Lucina pectinata (Mollusca: Lucinidae)
}

\author{
M. M. Ribeiro ${ }^{a}$, J. B. Oliveira ${ }^{a}$ and G. Boehs ${ }^{a *}$ \\ aDepartamento de Ciências Biológicas, Universidade Estadual de Santa Cruz - UESC, Rodovia Ilhéus-Itabuna, Km 16, \\ CEP 45662-900, Ilhéus, BA, Brazil \\ *e-mail: gboehs@uesc.com
}

Received: May 13, 2016 - Accepted: September 13, 2016 - Distributed: February 28, 2018

(With 2 figures)

\begin{abstract}
Lucina pectinata is an important economic resource in the Brazilian coast. This study reports parasitism caused by a Digenea in this species. The specimens $(n=470)$ were collected in December 2012 in a mangrove swamp of the Cachoeira River estuary, Bahia, Brazil. They were measured along the anterior-posterior axis (length), and after macroscopic analysis for parasites and diseases cuts of $5 \mathrm{~mm}$ were fixated in Carnoy's solution and processed by routine histology technique wherein sessions of $7 \mu \mathrm{m}$ were stained with Harris hematoxylin and eosin (H\&E). The tissues were examined using an optical microscope. The mean length of $L$. pectinata was $4.0 \pm 0.53 \mathrm{~cm}$. Microscopic analysis showed sporocysts containing both germ balls as cercariae of an unidentified Digenea (Platyhelminthes), these in various stages of development. The prevalence was $1.48 \%$ (7/470). In a parasitized specimen was macroscopic evidence of tissue densification of gills. The sporocysts were observed in mantle, gills, digestive gland and gonads, with evident alteration/destruction of tissues, including parasitic castration. There were no other parasites found, which is probably related to inaccessibility and chemical conditions in which lives L. pectinata, i.e., between 10 and $20 \mathrm{~cm}$ in mangrove sediment.
\end{abstract}

Keywords: marine bivalves, pathology, parasitism, fishing resources.

\section{Parasitismo por um Digenea em Lucina pectinata (Mollusca: Lucinidae)}

\section{Resumo}

Lucina pectinata é um importante recurso econômico na costa brasileira. Este estudo relata parasitismo causado por um Digenea nesta espécie. Os exemplares $(n=470)$ foram coletados em dezembro de 2012 em um manguezal do estuário do Rio Cachoeira, Ilhéus, Bahia. Estes foram medidos quanto ao eixo ântero-posterior (comprimento) e após análise macroscópica quanto a parasitos e enfermidades, cortes transversais de $5 \mathrm{~mm}$ foram fixados em solução de Carnoy e processados por técnica rotineira de histologia, sendo que sessões de $7 \mu \mathrm{m}$ foram coradas com hematoxilina de Harris e eosina (HE). Os tecidos foram examinados em microscopia de luz. A média de comprimento de L. pectinata foi de 4,0 $\pm 0,53 \mathrm{~cm}$. A análise microscópica evidenciou esporocistos de um Digenea (Platyhelminthes) não identificado, contendo massas germinativas e cercárias, estas em vários estágios de desenvolvimento. A prevalência foi de $1,48 \%$ (7/470). Um dos exemplares parasitado apresentou adensamento dos tecidos nas brânquias. Os esporocistos foram observados no manto, brânquias, glândula digestiva e gônadas, causando evidente alteração/destruição de tecidos, inclusive castração parasitária. Não foram observados outros parasitos, o que está provavelmente associado à inacessibilidade e condições químicas em que vive este hospedeiro, isto é, entre 10 e $20 \mathrm{~cm}$ no sedimento do manguezal.

Palavras-chave: bivalves marinhos, patologia, parasitismo, recursos pesqueiros.

\section{Introduction}

Lucina pectinata (Gmelin, 1791) (Bivalvia: Lucinidae) occurs from North Caroline (USA) to Santa Catarina, southern Brazil, living in mangrove sediment, at 10 to $20 \mathrm{~cm}$ of profundity (Rios, 2009), a region which occurs depletion of oxygen (Wilson and Fleeger, 2012). The Lucinidae feeds by filtering organic particles obtained directly from sediment (Morton, 1983). Proteobacteria sulfide-oxidative mandatory endosymbiotics also collaborates with these bivalves alimentation, contributing with organic compounds generated from chemosynthesis (LePennec et al., 1988).

Lucina pectinata is consumed and commercialized in coastal regions of Brazil and is of socioeconomic interest for coastal communities.

Digeneans, previously termed digenetic trematodes, are heteroxenous (i.e they require more than one host to complete their life cycle), their adult stage is parasitic in vertebrates, with larval development occurring mostly in 
molluscs (Paperna, 1995). The taxonomic status of Digenea is very confusing due to the complex life cycle that the species of this group present (Figueras and Villalba, 1988).

Digeneans are important parasites of bivalve molluscs, including several marine species of economic interest in which can cause serious damage (Lauckner, 1983). The larval stage is usually difficult to identify by histology, requiring methods like cercariae excision, experimental cycle or make use of molecular tools. These parasites has been reported in several bivalves of economic interest of the Brazilian coast (Boehs et al., 2012), but there are no records in L. pectinata except by Santana (2010) in the state of Ceará, northeast Brazil. Zeidan et al. (2012) investigated this species in southern Bahia concerning to parasitism and they have not registered any parasite, unlike they obtained in other two bivalves collected in the same locations.

This study reports parasitism caused by a Digenea (Platyhelminthes) in L. pectinata from Cachoeira River, southern Bahia, Brazil.

\section{Material and Methods}

The specimens of L. pectinata $(\mathrm{n}=470)$ were obtained from a mangrove swamp, in Cachoeira River, Ilhéus, Bahia (1447'01'S - 1449'25" S; 3903'22”W - 39 $04^{\prime} 43^{\prime \prime}$ W) (Figure 1), by manual collection in December 2012. According to the Köppen classification, the local climate is hot and tropical humid (Af), with an average annual temperature of $24.6^{\circ} \mathrm{C}$ and abundant rainfall (exceeding 2,000 mm annually) irregularly distributed throughout the year (Souza, 2005). It is known that the estuarine region of the Cachoeira River is a eutrophic environment due the input from industrial and domestic sewage and agricultural activities (Klump et al., 2002).

After collected, the specimens were transported to the Marine Mollusks Laboratory (MML) of the State University of Santa Cruz (UESC). The specimens collected were measured along the anterior-posterior axis (length) with the aid of digital caliper and dissected using a scalpel, without anesthetic use. After macroscopic analysis for parasites or signs of disease, transversal sections with about $5 \mathrm{~mm}$ were fixed in Carnoy's solution (ethanol, chloroform and glacial acetic acid in the ratio of 6: 3 : 1) for 1 hour, that went dehydrated in ethanol series, and embedded in paraffin. Thin-sections of $7 \mu \mathrm{m}$ were stained with Harris's haematoxylin and eosin (H\&E) followed by the preparation of slides (Howard et al., 2004). The tissues were examined using an optical microscope (Olympus CX31). The prevalence ( $\mathrm{P} \%$ ) was calculated as follow: $\mathrm{P} \%=(\mathrm{n} / \mathrm{t}) \times 100$, where $\mathrm{n}=$ number of infected specimens and $\mathrm{t}=$ total number of analyzed specimens x 100 (Bush et al., 1997).

\section{Results and Discussion}

The average length of $L$. pectinata was $4.0 \pm 0.53 \mathrm{~cm}$ $(n=470)$. The sex ratio male: female was 2.03: 1 . The single parasite evidenced by microscopic analysis was an unidentified digenean (Platyhelminthes). In a parasitized

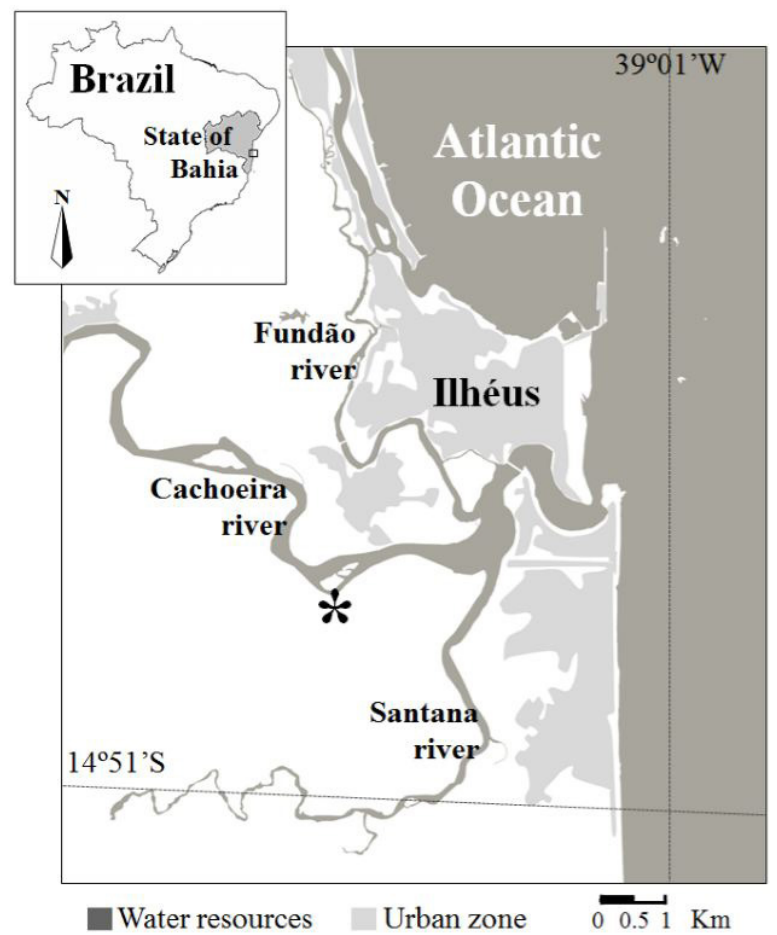

Figure 1. Point of collection (*) of Lucina pectinata in the estuarine region of the Cachoeira river, Bahia, northeastern Brazil. 

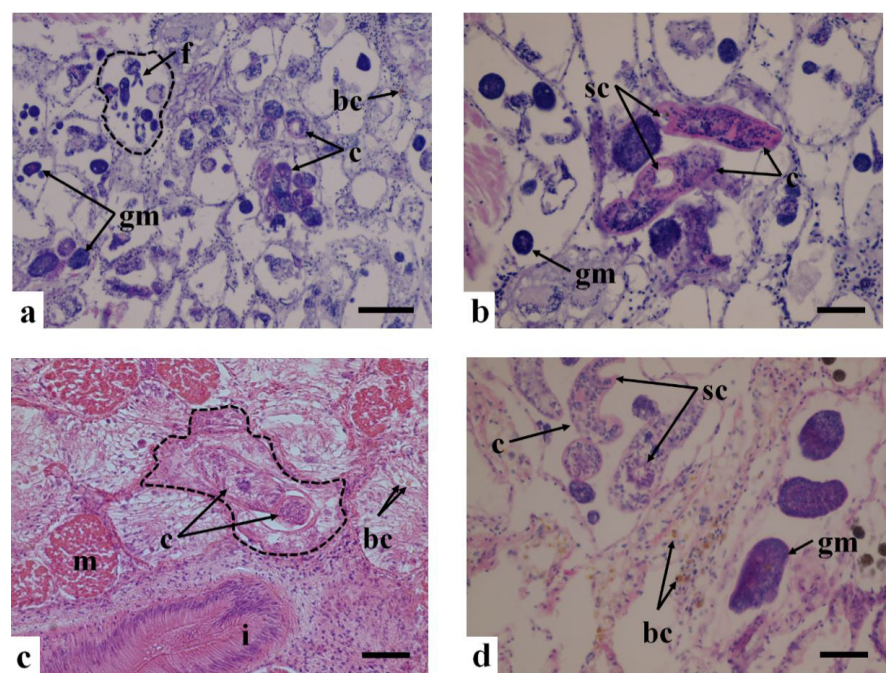

Figure 2. An unidentified Digenea in the connective tissue of Lucina pectinata from south coast of Bahia. a) Generalized destruction of gonads and digestive gland, with presence of sporocysts containing cercariae and germinative masses (balls); bar $=100 \mu \mathrm{m}$. b) Cercariae with ventral sucker and germinative masses; bar $=50 \mu \mathrm{m}$. c) Sporocyst with a cercaria, and brown cells; bar $=50 \mu \mathrm{m}$. d) Cercariae in the connective tissue; bar $=50 \mu \mathrm{m}$. Dotted line $=$ sporocyst; bc $=$ brown cell; $\mathrm{c}=$ cercariae $; \mathrm{f}=$ bifurcate tail $; \mathrm{gm}=$ germinative mass $; \mathrm{i}=$ intestine $; \mathrm{m}=$ muscle $; \mathrm{sc}=$ sucker.

specimen was macroscopic evidence of gills tissue densification. Sporocysts containing inside germinative balls (masses) and cercariae in various development stages (some with a ventral oral sucker and a bifurcate tail) were observed in mantle, gills, digestive gland, and gonads (Figure 2). The asynchrony in the development of cercariae allows their release in water for long periods of time (Laruelle et al., 2002).

The parasite caused evident tissue destruction, especially of follicles and germ cells, resulting in parasitic castration. Commitment of circulatory system, disorders in gametogenesis, destruction of reproductive follicles and consecutive castration were previously reported (Lauckner, 1983; Bower et al., 1994), the mechanic action and the decomposition of tissues are the main causes of damage by these parasites (Winstead et al., 2004). In this study was not observed hemocytic infiltration, but Boehs et al. (2010) identified it for sporocysts in degenerative phase or already dead. Brown cells (= rhogocytes) were observed near the parasites (Figure 2). These cells can act in removal residues and other products associated to parasitism conditions (Cheng and Burton, 1966).

The prevalence of this Digenea in L. pectinata was $1.48 \%(n=470)$, which was considered low and convergent to previous studies conducted in south coast of Bahia. The maximum prevalence observed was $7.43 \%$ in A. brasiliana (Boehs et al., 2010), 9.9\% in M. guyanensis and 6.6\% in C. rhizophorae (Zeidan et al., 2012). Santana (2010), which recorded a digenean in gills and gonads of $L$. pectinata of Ceará, found prevalence of $15 \%$ in the rainy season and $5 \%$ in dry season in gills and $2.2 \%$ in gonads. Although the prevalence of digeneans in Brazilian bivalves has been registered normally between 5 and $8 \%$ (Boehs et al., 2012), studies realized in other regions of the country have shown higher values: Leite (2007) registered $66.3 \%$ in P. perna in Santa Catarina, southern Brazil and Ferreira et al. (2008) found $30 \%$ in A. brasiliana from estuary of Pacoti River, Ceará.

It was not observed any other parasite in L. pectinata tissues and this is probably associated to the depth of occurrence of this bivalve, which is 10 to $20 \mathrm{~cm}$. This is a physical barrier in terms of access of the parasites to the host. Moreover, in the mangroves, this depth has a natural condition of hypoxia or anoxia. These conditions possibly limits establishment of many pathogens.

\section{Acknowledgements}

We thank FAPESB for the financial support (TSC 0010/2011) and scholarship to the first author. To Marina B. da Silva for English review.

\section{References}

BOEHS, G., MAGALHÃES, A.R.M., SABRY, R.C. and CEUTA, L.O., 2012. Parasitos e patologias de bivalves marinhos de importância econômica da costa brasileira. In: A.T. SILVA-SOUZA, M.A.P. LIZAMA and R.M. TAKEMOTO, orgs. Patologia e sanidade de organismos aquáticos. Maringá: Associação Brasileira de Patologistas de Organismos Aquáticos - ABRAPOA, pp. 165-194.

BOEHS, G., VILLALBA, A., CEUTA, L.O. and LUZ, J.R., 2010. Parasites of three commercially exploited bivalve mollusc species of the estuarine region of the Cachoeira River (Ilhéus, Bahia, Brazil). Journal of Invertebrate Pathology, vol. 103, no. 1, pp. 43-47. PMid:19850046. http://dx.doi.org/10.1016/j.jip.2009.10.008.

BOWER, S.M., MCGLADDERY, S.E. and PRICE, I.M., 1994. Synopsis of infectious diseases and parasites of commercially exploited shellfish. Annual Review of Fish Diseases, vol. 4, no. 1, pp. 1-199. https://doi.org/10.1016/0959-8030(94)90028-0. 
BUSH, A.O., LAFFERTY, K.D., LOTZ, J.M. and SHOSTAK, A.W., 1997. Parasitology meets ecology on its own terms: Margolis et al. revisited. The Journal of Parasitology, vol. 83, no. 4, pp. 575-583. PMid:9267395. http://dx.doi.org/10.2307/3284227.

CHENG, T.C. and BURTON, R.W., 1966. Relationships between Bucephalus sp. and Crassostrea virginica: a histochemical study of some carbohydrates and carbohydrate complexes occurring in the host and parasite. Parasitology, vol. 56, no. 1, pp. 111-122. PMid:4161765. http://dx.doi.org/10.1017/S0031182000071134.

FERREIRA, L.P., SABRY, R.C., DA SILVA, P.M., ROMÃO, L.S., ARAÚJO, R.L., SILVEIRA, F.F. and GESTEIRA, T.C.V., 2008. Ocorrência de parasitas em Anomalocardia brasiliana (Bivalvia: Veneridae) do Estuário do Rio Pacoti, Ceará. In: Anais do X Encontro Brasileiro de Patologistas de Organismos Aquáticos, 17-20 Novembro 2008. Búzios, Brasil. Búzios: Associação Brasileira de Patologistas de Organismos Aquáticos-ABRAPOA, pp. 17-20.

FIGUERAS, A.J. and VILLALBA, A., 1988. Patología de moluscos. In: J.E. MONTEROS and U. LABARTA, eds. Patología en acuicultura. Madrid: FEUGA, Mundi-Prensa Libros, p. 327-389.

HOWARD, D.W., LEWIS, E.J., KELLER, B.J. and SMITH, C.S., 2004. Histological techniques for marine bivalve mollusks and crustaceans. 2nd ed. Oxford: NOAA/National Centers for Coastal Ocean Science. 218 p. NOAA Technical Memorandum NOS NCCOS, no. 5.

KLUMP, A., BAUER, K., FRANZ-GERSTEIN, C. and DE MENEZES, M., 2002. Variation of nutrient and metal concentrations in aquatic macrophytes along the Rio Cachoeira in Bahia (Brazil). Environment International, vol. 28, no. 3, pp. 165-171. PMid:12222613. http://dx.doi.org/10.1016/S01604120(02)00026-0.

LARUELLE, F., MOLLOY, D.P. and ROITMAN, V.A., 2002. Histological analysis of trematodes in Dreissena polymorpha: their location, pathogenicity and distinguishing morphological characteristics. The Journal of Parasitology, vol. 88, no. 5, pp. 856-863. PMid:12435120. http://dx.doi.org/10.1645/00223395(2002)088[0856:HAOTID]2.0.CO;2.

LAUCKNER, G., 1983. Diseases of Mollusca: Bivalvia. In: O. KINNE, ed. Diseases of marine animals. Hamburg: Biologische Anstalt Helgoland, pp. 478-961.
LEITE, L.A., 2007. Influência da predação, parasitismo e densidade de sementes nas perdas de mexilhões Perna perna (L., 1758), cultivados na Baía Norte da Ilha de Santa Catarina. Florianópolis: Universidade Federal de Santa Catarina, 39 p. Dissertação de Mestrado em Aquicultura.

LEPENNEC, M., DIOURIS, M. and HERRY, A., 1988. Endocytosis and lysis of bacteria in gill epithelium of Bathymodiolus thermophilus, Thyasira flexuosa and Lucinella divaricata (Bivalve, Molluscs). Journal of Shellfish Research, vol. 7, no. 3, pp. 483-489.

MORTON, B., 1983. Feeding and digestion in Bivalvia. In: A.S.M. SALEUDDIN and K.M. WILBUR, eds. The Mollusca: Physiology, Part 2. New York: Academic Press, vol. 5, pp. 65-147.

PAPERNA, I., 1995. Digenea (Phylum Platyhelminthes). In: P.T.K. WOO, ed. Fish diseases and disorders. Volume 1: Protozoan and Metazoan Infections. Wallingford: CAB International, pp. 329-389.

RIOS, E.C., 2009. Compendium of Brazilian sea shells. Rio Grande: Evangraf. 676 p.

SANTANA, L.M.B.M., 2010. Biologia Reprodutiva e Considerações sobre Parasitismo em Lucina pectinata (Mollusca: Bivalvia) em um estuário tropical. Fortaleza: Universidade Federal do Ceará, 86 p. Dissertação de Mestrado em Ecologia e Recursos Naturais.

SOUZA, M.F.L., 2005. Nutrient biogeochemistry and mass balance of a tropical estuary: estuary of Cachoeira River, Northern Brazil. International Journal of Ecology and Environmental Sciences, vol. 31, no. 3, pp. 177-188. http://dx.doi.org/10.1590/ s1679-87592014051306201.

WILSON, J.G. and FLEEGER, J.W., 2012. Estuarine benthos. In: J.W. DAY, B.C. CRUMP, W.M. KEMP and A. YÁÑEZARANCIBIA, eds. Estuarine ecology. Hoboken: Wiley Blackwell, pp. 303-325. http://dx.doi.org/10.1002/9781118412787.ch12

WINSTEAD, J.T., VOLETY, A.K. and TOLLEY, S.G., 2004. Parasitic and symbiotic fauna in oysters (Crassostrea virginica) collected from the Caloosahatchee River and estuary in Florida. Journal of Shellfish Research, vol. 23, no. 3, pp. 831-840.

ZEIDAN, G.C., LUZ, M.S. and BOEHS, G., 2012. Parasites of economically important bivalves from the southern coast of Bahia State, Brazil. Revista Brasileira de Parasitologia Veterinária, vol. 21, no. 4, pp. 391-398. PMid:23295820. http://dx.doi.org/10.1590/ S1984-29612012000400009. 